\title{
Current research on the Ilímassaq alkaline intrusion, South Greenland
}

\section{Henning Bohse, Lotte Melchior Larsen, John Rose-Hansen, C. Overgaard Nielsen and Henning Sørensen}

Research projects described in GGU Reports of Activities for 1971, 1972 and 1973 all continue.

The 1974 season's field work on the Ilímaussaq region was centred around the following projects:

\section{Lujavrites at and near the Kvanefjeld plateau (H. Sørensen)}

The distribution of the varieties of lujavrite enriched in uranium was investigated. Larger samples were collected at a number of localities. The material will be studied in the Institute of Petrology and an experimental examination of the extraction of uranium from the rocks will be carried out in the Chemistry Department of the Danish Atomic Energy Commission's Research Establishment, Ris $\emptyset$.

\section{Alkaline dykes in and around the Ilimaussaq intrusion (Lotte Melchior Larsen)}

The dyke swarms associated with the individual plutonic centres in the Gardar province have in recent years gained increasing attention because, being better approximations to liquid compositions than the rocks of the plutonic centres, they bear some of the best evidence of the different compositional spectra of liquids generated in the various regions of the province.

Tying up with other investigations of differentiated dykes in the Grønnedal-Íka area (Gill, 1972), on Tugtutôq (Macdonald, 1969) and in the South Qoroq centre (D. Stephenson, unpublished work), a field and laboratory investigation of dykes in the Ilímaussaq region has been initiated. A number of undersaturated, more or less peralkaline, aphyric and porphyritic dykes, occur inside and outside the Ilímaussaq intrusion. The field work benefited much from the earlier mapping of Ferguson (1964), Hamilton (1964), and Allaart (1969). Laboratory work is currently in progress. The dykes in this area seem to be higher in iron and alkalis than other Gardar dykes, a feature also exhibited by the llimaussaq intrusion, compared to other Gardar intrusions, and probably of principal genetic significance. Some of the dykes may not represent the original liquid compositions due to loss of alkalis and volatiles during crystallisation. The effect of this process can be evaluated both qualitatively and semiquantitatively, as shown by Larsen \& Steenfelt (1974) for one of the dykes in the region.

\section{Field mapping of green aegirine lujavrite (Henning Bohse)}

The field work was confined to the area south of Lakseelv, that is Laksefjeld and the area between the two branches of the upper part of Lakseelv. The green aegirine lujavrites of this area can be divided into a lower and an upper part. 
The lower part has a thickness of $80 \mathrm{~m}$. The rocks are distinctly laminated and display a strong fissility. The rock is everywhere fine-grained, the grain-size descreasing when passing up through the rock sequence. Alternation of layers characterised by differences in the proportion of modal microcline and nepheline produces a banding in the lujavrite. Differential weathering makes these alternating bands distinguishable even at long distance. The lower boundary of the lower division is continuous and there is a gradual transition into the underlying kakortokite. This takes place by means of a gradual decrease in the content of aegirine over a distance of some metres. The uppermost layer of white kakortokite is underlain by red layer number A (Bohse et al., 1971) which is always underlain by a $1 \mathrm{~m}$ thick layer of green lujavrite (Demin, 1970). This unit was found in the area between the two branches of the upper part of Lakseelv. A correlation will therefore be possible with the same unit previously mapped by the author at Laksefjeld and in the area north of Lakseelv at the head of the Kangerdluarssuk fjord.

The upper part of the green lujavrite was found at two localities. This rock also has a good lamination and a strong fissility, but it is usually finer-grained than the lower lujavrite, with a lighter green colour, owing to the smaller size of the aegirine needles. In many localities there are globular nodules up to $5 \mathrm{~cm}$ across composed of natrolite and yellow analcime. These nodules are enclosed by lujavrite which displays flow structures around the nodules. The globular nodules in the lujavrite may have been formed from liquids immiscible with the lujavrite magma.

The boundary between the two divisions of lujavrite is disturbed by hydrothermal/ pneumatolytic alteration. Erosion has removed the upper part of the green lujavrite but at least $30 \mathrm{~m}$ were measured at Lakseelv, although less is present at Laksefjeld.

\section{Environmental geochemistry and ecology (C. Overgaard Nielsen, J. Rose-Hansen \& H. Sørensen)}

This project is arranged jointly by GGU and the State Research Council for Natural Sciences with financial support from the Research Council and logistic support from GGU.

The purpose of the project is to compare the exogeneous geochemical and ecological environment in selected regions within the Ilímaussaq intrusion with that of selected regions outside the intrusion in which the solid rocks consist of Julianehåb granite.

The project is based on detailed mapping and description of selected areas and on extensive sampling of solid rock, weathering products, soil, glacial deposits, water in lakes, rivers and fjords and biological material.

In this project the hydrology and water balance of selected river systems is studied and meteorological observations are carried out. This is a continuation of the study in the Narssaq river drainage basin since 1965, as a Danish contribution to the International Hydrological Decade Program (Hansen \& Pulawski, 1966; Larsen, 1972).

Based on a large number of chemical analyses, mainly obtained by instrumental neutron activation analysis, the behaviour of selected trace elements during weathering and biological processes will be studied. In particular, an attempt will be made to 
follow some of the rare elements of the geochemically unique Ilímaussaq rocks. The analytical work is in progress.

The results obtained during this study will be used in planning the monitoring of the effects of mining activity on the geochemical and biological environment and in evaluation of global geochemical processes.

\section{References}

Allaart, J. 1969: The chronology and petrography of the Gardar dykes between Igaliko Fjord and Redekammen, South Greenland. Rapp. Grønlands geol. Unders. 25, 26 pp.

Bohse, H., Brooks, C. K. \& Kunzendorf, H. 1971: Field observations on the kakortokites of the Ilimassaq intrusion, South Greenland, including mapping and analyses by portable Xray fluorescence equipment for zirconium and niobium. Rapp. Grønlands geol. Unders. 38, 43 pp.

Demin, A. 1970: Detailed mapping in the southern part of the Ilímaussaq intrusion (Kangerdluarssuk fjord). Rapp. Gronlands geol. Unders. 35, 29-30.

Ferguson, J. 1964: Geology of the Ilímaussaq alkaline intrusion, South Greenland. Description of map and structure. Bull. Grønlands geol. Unders. 39 (also Meddr Grønland 172,4) 82 pp.

Gill, R. C. O. 1972: Chemistry of peralkaline phonolite dykes from the Grønnedal-Íka area, South Greenland. Contr. Miner. Petr. 34, 87-100.

Hamilton, E. I. 1964: The geochemistry of the northern part of the Ilímaussaq intrusion, SW Greenland. Bull. Grønlands geol. Unders. 42 (also Meddr Grфnland 162,10) 104 pp.

Hansen, J. \& Pulawski, B. 1966: Water balance in Narssaq river valley. Rapp. Gronlands geol. Unders. 11, 50-51.

Larsen, L. B. 1972: Hydrological project at Narssaq Bræ, south Greenland, as part of the International Hydrological Decade Programme. Rapp. Grønlands geol. Unders. 45, 27-29.

Larsen, L. M. \& Steenfelt, A. 1974: Alkali loss and retention in an iron-rich peralkaline phonolite dyke from the Gardar province, south Greenland. Lithos 7, 81-90.

Macdonald, R. 1969: The petrology of alkaline dykes from the Tugtutôq area, south Greenland. Bull. geol. Soc. Denmark 19, 257-282.

Institut for Petrologi, $\emptyset$ ster Voldgade 5-7, 1350 Copenhagen $K$. 